\title{
Into the Reading Methodology of an EFL Teacher: A Way to Improve the Students' Academic Achievement for the National-High-School-Graduation Examination
}

\author{
Jorge Altamirano Alvarado \\ Sede Regional Brunca \\ Universidad Nacional, Costa Rica \\ Manuel Navarro Godínez \\ Liceo San Antonio de Pejibaye \\ Pérez Zeledón, Costa Rica
}

\begin{abstract}
In this article, we explore the methodology that an EFL teacher developed for his students during their teaching-learning process in order to improve the academic achievement of the students for the NationalHigh-School-Graduation Examination (Bachillerato Exam) in the coming years. This study was conducted at public high school from Buenos Aires, Puntarenas and was addressed to one-eleventh-grade group. Based on the research findings, we intended to coach the teacher and to advise him about the plausible methodological line he might follow in terms of techniques, strategies, and skills in order to have his students increase their academic achievement for passing the National-High-School-Graduation Exam in the future.
\end{abstract}

Key words: methodology, academic achievement, techniques, strategies, skills, reading approach, reading comprehension, teaching

\section{Resumen}

En este artículo, exploramos la metodología empleada por un docente de inglés durante el proceso de enseñanza y aprendizaje, con el propósito de mejorar el rendimiento académico de sus discentes para el examen de inglés de bachillerato en los años venideros. El estudio se desarrolló al 
eliminar la posible dirección metodológica que el docente podría usar en clase para que los estudiantes puedan mejorar el rendimiento académico y aprobar el examen de inglés de bachillerato. Contempló un grupo de 19 estudiantes de undécimo nivel de un colegio público de Buenos Aires de Puntarenas. Según los resultados obtenidos, los investigadores ofrecieron capacitación metodológica y retroalimentación.

Palabras claves: metodología, rendimiento académico, estrategias, técnicas, habilidades, enfoque metodológico de lectura, comprensión de lectura, enseñanza

\section{Introduction}

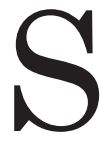
econd language learning is an ongoing process since knowledge of a target language is always emerging. In fact, for a long time, the teaching of a second tongue has been done through the development of the four skills. Brown (2001) states that "for more than six decades now, research and practice in English language teaching has identified the "four skills"-listening, speaking, reading and writing- as of paramount importance. ESL curricula and textbooks around the world tend to focus on one or two of the four skills, sometimes to the exclusion of the others" (p. 232). This is the case of the reading skill, which is probably treated in a separate segment by Costa Rican teachers, for the NationalHigh-School-Graduation Examination focuses on multiple-choice-readingcomprehension questions.

For years, the teaching of English in Costa Rican public middle and high schools has been limited to a great extent to the development of a teaching methodology focused on both reading strategies and techniques, along with the memorization of grammar structures and vocabulary items. Such methodology is developed since students need to pass the National High-School
Graduation Exam at the end of the school year. As a result, various teachers might still believe that teaching reading centers on providing learners with a whole lot of lists of vocabulary and structures in isolation and rotereading comprehension exercises that often thwart the students and may result in apathy towards the target language. In fact, teaching reading comprehension is a process that goes beyond giving learners texts and long lists of unknown words for them to memorize and then solve a set of written exercises. Certainly, it implies complex cognitive, metacognitive, and critical thinking skills for decoding, understanding, making inferences, and interpreting text taking into account textual and contextual clues.

Added to this, grammar and vocabulary are two core areas of language that complement the teaching of English in Costa Rica. In a study carried out with tenth and eleventh graders in private and public, urban and rural high schools in Heredia about the methodology used by teachers, the implementation of the Communicative Approach and its relationship with the NationalHigh-School-Graduation Examination, Domian et al (2010) state that "grammar and vocabulary predominate as the teaching methodology" (p. 47). Such an argument clearly points out 
that many English teachers in Costa Rica do not follow a communicative methodology as part of their daily lessons. Indeed, in various Costa Rican communities, several EFL teachers working in public schools might focus their academic English lessons on the development of both reading strategies and techniques due to the previously mentioned nature of the National High-School Graduation Exam. This methodology variation is probably the result of teachers developing areadingcomprehension-oriented methodology as a way to have students pass the National-High-School-Graduation Test. As to this point, Quesada affirmed: "many teachers receive some plausible pressure in order for them to teach for the National-High-School-Graduation Exam" (qtd. in Domian et al, 2010, p. 47). In sum, most high school principals are concerned about numbers, namely, they are interested in obtaining the best National-Graduation Examination achievement level and the highest test scores.

In sum, one key factor that seemed to be affecting the communicative teaching of English is the development of an effective methodology. Hence, it is highly necessary for an instructor to pick out a methodology with a rationale and tenets that are oriented to his learners' needs. Although the methodology a teacher uses for teaching a lesson constitutes an important component of the students' academic achievement, there are other factors that might affect their progress such as aptitude, motivation, age, learner types, anxiety, self-confidence, relationship to the teacher, and attitude towards language learning (Lindsay and Knight, 2006). This means that while some language teachers might use integrated-skills oriented methods, others may focus their EFL lessons on reading. Furthermore, the washback or backwash effect (the influence of a test on teaching) could also affect the academic achievement of the students since the backwash effect might bring on an either positive or negative impact on the students' test scores.

By and large, the research revolves around the exploration of the methodology that the EFL teacher from a public high school, in Buenos Aires, Puntarenas develops for his students during their teaching-learning process. This is in order to gain insights to make progress in terms of their academic achievement as to the minimum grade (70) to pass the NationalHigh-School-Graduation Examination. This means that if a student increases comprehension, he will enhance his academic achievement in terms of test scores. As a result, pupils might not fail a reading test or course if they are exposed to a reading-skill-building process since they are in seventh grade. Since MEP grades the National-HighSchool-Graduation Test quantitatively, it results necessary for any teacher of English to develop a reading methodology that aids learners to increase comprehension in order to obtain passing test scores.

The following table shows the Test Promotion rate of the public school under this study during three years: 
Table 1

National-High-School-Graduation Exam Promotion from to 2012 to 2014.

\begin{tabular}{cccc}
\hline Year & $\mathbf{2 0 1 2}$ & $\mathbf{2 0 1 3}$ & $\mathbf{2 0 1 4}$ \\
\hline $\begin{array}{c}\text { Percentage of } \\
\text { Promotion }\end{array}$ & $49.60 \%$ & $54 \%$ & $41.66 \%$ \\
\hline
\end{tabular}

Source: Data taken from Reports of MEP Board of Quality Control.

In 2014, the results of the National-High-School-Graduation Examination were rather low and alarming, for only 5 out of 12 students taking the English test were able to pass it. Namely, $41.66 \%$ of the pupils passed it, and 58.34\% failed it. On this account, such results were a matter of concern to all high school faculty staff, and an immediate intervention was required. At this time, it is difficult to assert why a quantitative difference affected test promotion from one year to another, considering the fact that the same teacher taught the three generations.

In this study, the following research questions arose:

1. What target contents and linguistic objectives does the English teacher from Liceo Concepción de Pilas use with eleventh graders as part of his teaching methodology?

2. How does the EFL teacher from Liceo Concepción de Pilas teach reading comprehension to eleventh graders for the National-HighSchool-Graduation Examination?

3. What are the test items that most eleventh graders failed in the National-High-School-Graduation Test in terms of the reading strategies that were involved?

\section{Theoretical Considerations}

The teaching of reading has become a topic of discussion in the field of education studies since teaching reading might seem an easy job to do. Rather, this process is cumbersome, for a teacher teaches a student to build his own understanding of print in order to convey meaning.

It is important to clarify the definitions of the terms reading and comprehension that this research study abides by. The former accounts for an eloquent process whereby learners blend schemata and text content in order to construct and express meaning. Anderson states: "Reading is a fluent process of readers combining information from a text and their own background knowledge to build meaning" (qtd. in Nunan, 2003, p. 68). The latter is comprehension, which is the goal of the reading process. Comprehension is the proper perception a reader has of a text. According to Anderson, "reading is understood as the core and most important goal of literacy, and it contains four important elements: strategies or techniques, fluency, the reader and the text (qtd. in Nunan, 2003, 68). All of the previously mentioned aspects combined make reading a meaningful process that leads pupils to successful comprehension.

As stated before, reading is an essential skill for all people, particularly for learners of English as both foreign and second language. The majority of literacy teachers are concerned about students being able to understand what a text is all about. By using steady reading strategies, techniques and skills pupils might be able to make progress and develop other areas of learning. 
In fact, there are different principles for teaching reading. Notwithstanding, the following are key tenets that revolve around the teaching of second language reading.

Schemata is of paramount importance to reading. If students are not knowledgeable enough to understand a text, even if their decoding skills and lexicon are adequate, the text will be non-sense. Clarke and Silberstein capture the essence of schema theory:

Research has shown that reading is only incidentally visual. More information is contributed by the reader than by the print on the page. That is, readers understand what they read because they are able to take the stimulus beyond its graphic representation and assign it membership to an appropriate group of concepts already stored in their memories... Skill in reading depends on the efficient interaction between linguistic knowledge and knowledge of the world. (qtd. in Brown, 2001, 299-300)

In short, schema theory refers to the reader's background knowledge, that is, all of the experiences that a reader brings to a text. In addition, schemata deals with cultural background, and knowledge of the world and discourse structure. In order to activate schemata, it is necessary for the teacher to set goals, ask questions, make predictions, teach a text structure, and so on (Nunan, 2003, p. 74).

Vocabulary plays a very important role in reading comprehension. The more terms a student knows, the easier understanding a text might be. Likewise, the teaching of vocabulary on the part of a teacher should be selective, meaningful, and contextualized. Regarding the teaching of vocabulary Nunan (2003) points out:

Learners see vocabulary as being a very important part of language learning and one of the difficulties in planning the vocabulary component of a course is making sure that it does not overwhelm other essential parts of the course. The best way to avoid this is for the teacher and course designer to have a set of guiding principles that can be applied in a variety of teaching and learning situations. (p. 135)

This means that vocabulary teaching should be carefully selected and taught by means of visual aids or simple definitions derived from the students' background knowledge. A teacher should not introduce many new terms to the students per session since memory is temporary, and pupils may forget them easily if the teacher overwhelms them with large lists of unknown words in isolation.

Motivation determines the way in which a person learns to read. Hence, learners need to be willing to learn. Just as the teaching of a foreign language includes a variety of approaches and techniques, the teaching of reading also incorporates an array of teaching approaches and strategies that contribute to the enhancement of comprehension. No specific recipe or single approach can guarantee the complete success when teaching a target-content to reach a particular goal from a syllabus. That is, no approach is better than other is. In fact, Nunan (2003) points out, "It should be clear from the foregoing that as both an enlighted and eclectic teacher, you think in terms of a number of possible methodological 
options at your disposal for tailoring classes to particular contexts" (p. 42). In this regard, the development of an eclectic approach or a combination of several approaches seems to be a good choice to fulfill previously established aims. In both ESL and EFL teaching, the reading process comprises various models: bottom-up models, top-down models, interactive models, and the balanced reading model.

Nonetheless, the Balanced Reading Approach certainly delves to scaffold students' learning and fosters their success. Cooper (2014) expresses that a Balanced Reading Approach is composed of the following elements: modeled reading (reading aloud and verbalization), shared reading (reading along with other peers), guided reading (student talk and reading strategies), collaborative reading (pair or group work developing silent or oral reading for further discussion), and independent reading (learners' choices of their own reading passages and individual work promoting competence, enjoyment and confidence). In short, the BalancedReading Approach constitutes a good alternative for teachers to offer students carefully structured support (scaffolding), guiding them in the right direction until the students have built strong knowledge and understanding of the contents taught (Cooper, 2014).

A well-developed reading methodology also comprises the use of a variety of techniques, strategies, and skills. Though the three terms seem to be similar, they are not the same.

Brown (2001) defined techniques as "any of a wide variety of exercises, activities, or tasks used in the language classroom for realizing lesson objectives" (p. 16). That is to say, techniques involve using any didactic tool, resource or group of procedures that contribute to reaching a set of desired goals.

Research shows that the use of effective techniques for teaching reading is essential for comprehension. Armbruster and Osborn state that "Explicit teaching techniques are particularly effective for comprehension strategy instruction. In explicit instruction, teachers tell readers why and when they should use strategies, what strategies to use and how use them" (Armbruster and Osborn, 2001, p. 53). In fact, teachers have an important quota of responsibility for helping learners choose appropriate reading strategies. Furthermore, teachers are responsible for using a reading approach or model with teaching techniques that increases students' reading comprehension. There is no single approach that is considered non-plus ultra in language teaching. In fact, a teacher can use multiple techniques in the classroom for teaching reading. Some examples of reading techniques are comprehension questions, antonyms/synonyms, cognates, memorization, gap filling exercises, semantic maps, reading aloud, silent reading, multiple-slot substitution drill, grammar games, classroom set-up, pair work, group work, jigsaw, prior knowledge activation, vocabulary building, diagram completion, visual aids, authentic material, and so forth (Larsen-Freeman, 2000). Summing up, text comprehension can be taught through explicit instruction and cooperative learning aiding students to develop strategies flexibly.

According to Oxford (1990), "Learning strategies are operations employed by the learner to aid the acquisition, 
storage, retrieval, and use of information" (p. 8).Though this definition is useful, it does not seem to transfer the richness of the concept of learning strategies. Accordingly, she offers a more complete definition by saying that "learning strategies are specific actions taken by the learner to make learning easier, faster, more enjoyable, more self-directed, and more transferrable to new situations" (p. 8). This means that learning strategies are learner-oriented, since students are the ones that develop them on their own. Some common examples of reading strategies a teacher may teach to his students are brainstorming, guessing meaning from context or context clues, getting main ideas, scanning for specific information, skimming, and making inferences.

In relation to skills, Nunan (2003) states: "a skill is a strategy that has become automatic" (p. 77). Through this definition, it is possible to foresee that students play an active role in reading. In fact, the teacher's methodology guides the student towards a strategic reading process. Moreover, "As learners consciously learn and practice specific reading strategies, the strategies move from conscious to unconscious; from strategy to skill" (Nunan, 2003, p. 77). As far as pupils are in contact with learning strategies, the strategies become more habitual to the students since they start using them more naturally and become skills, which are unconscious. In summary, strategies, techniques, and skills are essential elements to consider at the time of choosing an approach to teaching reading.

\section{Methodology, instruments, and participants}

This study was based on qualitative investigation and followed a descriptive design. We used two questionnaires, conducted one interview, did six non-participant observations, and analyzed artifacts (test booklets, teacher-tracking sheets, statistical reports, and lesson plans).

The study was conducted at a public high school from Buenos Aires, Puntarenas and addressed to a population of one-eleventh-grade group of 17 students (nine girls and eight boys). The class met twice on a weekly basis for five forty-minute lessons of academic English.

According to their English teacher, these students have reached different language proficiency levels. Their ages range from 16 to 20 years. All of this population has been in this school since seventh grade. Thus, they have had exposure to English for four years already. Furthermore, they are all nonnative speakers of English.

The second informant was a male English teacher in charge of the targetpopulation class. The teacher is a thirty-four-year-old-tenured educator, has a Bachelor's degree in English Teaching from a private university, has been teaching for more than 9 years, and has taught levels 1-11 in both elementary and high school.

\section{Discussion of findings}

Pre-established categories constituted the non-participant observation anecdotal record used to gather the subjects' teaching-learning process in 
the educational setting as to the teaching methodology for teaching reading developed by the EFL teacher. Each of the six classroom observations conducted was coded as follows: NPO1 corresponds to the first classroom observation done and NPO 6 represents the last nonparticipant observation carried out. The information collected from the observation was grouped into target content taught, linguistic objective, teaching material, role of language, role of the teacher, role of the students, teaching techniques, and reading strategies.

\section{Categories derived from non-par- ticipant observations}

a. Target contents: In NPO1, the teacher taught Science and Technology during two lessons. NPO2 and NPO3 comprised the target content of Minority Groups during two lessons each observation conducted. NPO4, NPO5, and NPO 6 involved the development of the last target content on Mass Media and Communications during two lessons each observation session.

b. Linguistic objectives: From NPO1 to NPO6, the most developed linguistic objectives were: Understanding a wide range of factual and imaginative texts, interpreting material that contains complex sentences, identifying the main point or important information in a piece of discourse, and distinguishing the main idea from supporting details. No linguistic objectives related to listening, speaking, and writing were taught albeit it was indicated in the teacher's trimestral plan.

c. Teaching material: From NPO1 to NPO4, the teacher used copies of readings and exercises from a booklet he has. After NPO4, the researcher coached the teacher. The teacher was provided with a reading skills-based lesson plan, three flash cards about Mass Media and Communications, and a text and a set of reading comprehension exercises based on skimming for main ideas, scanning for details, guessing meaning from context and making inferences. In NP05 and NPO6, the teacher implemented that plan along with the given materials.

d. Role of language: In NPO1 through NPO6, the teacher used the target language to explain or present a topic or concept. Nevertheless, he translated most of his discourse into Spanish for the students to understand. He performed double work. Some students answered some questions in English at a word or simple phrase level. None of the students was able to construct oral coherent sentences to answer questions.

e. Role of the teacher: During all the observations, the teacher directed and managed the class. The students listened to and followed directions to carry out the activities presented. In every lesson taught, the teacher played several different roles. In the case of a reading class, Wiriyachitra (1995) manifested that the reading teacher should be a counselor, a supporter, a motivator, a monitor, and an evaluator. Unfortunately, none of the previous roles suggested by Wiriyachitra (1995) was observed during NPO1 through NPO6.

f. Role of the students: The students were passive agents at all times. Some of them tried to answer a question if the teacher called their names. Otherwise, they remained silent. 
h. Teaching techniques: The teaching techniques observed were comprehension questions, memorization, gap filling exercises, multiplechoice practices, true-or-false items, silent reading, translation, pair work, group work, prior knowledge activation, and flashcards. The last two techniques were observed during NPO5 and NPO6.

i. Reading strategies: In NPO1 through NPO4, the students developed reading strategies such as scanning for information, using an on-line dictionary and a translator accessed through their smart phones. Main ideas, details, context clues, and inferences were developed in NPO5 and NPO6.

Coaching the teacher had a positive impact since he started to explain the language learning strategies for reading to the students in a more systematic way so that the students could understand what they were reading and were able to find the right answers to the questions given.

\section{Teacher questionnaire}

The EFL teacher provided very valuable data regarding his teaching methodology. Largely, he points out that he focuses his lessons mainly on reading comprehension, provides students with lists of vocabulary in isolation for memorization, and follows the distribution of objectives and contents for the National Examination rather than the English Syllabus. Likewise, he is willing to try new methodologies and techniques. Notwithstanding, seldom does he develop the three stages of the reading process (pre-reading, while reading and post-reading). In addition, he uses copies of readings with or without exercises, online magazines, papers or EFL textbooks.

Regarding his opinion about the National-High-School-Graduation Examination, he believes the test does not fully measure the students' knowledge since it does comprise the four skills. Moreover, he believes that pupils learn best through oral activities. In fact, he says that students in Costa Rica need to learn to speak English in order to get better job opportunities, but the National-High-School-Graduation Examination is a limitation for that because it focuses only on reading.

Finally, the teacher believes that the best way to teach English is by using authentic materials and various techniques. Added to this, he states that sometimes students feel bored because teaching reading comprehension is tiring. Hence, more student- motivation is necessary to get them on task. Wiriyachitra (1995) previously pointed out that the teacher should be a motivator; namely, he should foster student expectations about the reading and arouse their interest to read.

\section{Patterns discovered}

Because of the previous categories, new constructs or patterns emerged.

a. Absent reading stages: In NPO1 through NPO4, the teacher wrote the title of the topic and handed out copies of short reading passages and comprehension exercises for the students to solve. There were no prereading, while reading, and post-reading activities sequentially developed. The teacher went straight to the point when dealing with reading practices. 
In addition, his trimestral lesson plan evidenced a lack of activities for the three reading stages. No schemata was activated before reading. As previously manifested by Clark and Silberstein (qtd. in Brown, 2001), learners understand what they read because they can take the stimulus beyond its visual representation and assign it membership to an appropriate group of concepts already stored in their memories. Moreover, the development of successful reading skills has to do with the efficient interaction between linguistic knowledge and knowledge of the world. For this reason, activating schemata during a reading session results mandatory as a way to increase comprehension. After being coached by the investigator, in NPO5 and NPO6, the teacher developed a lesson plan with activities for the three reading stages. Some learners told the researcher that they felt like understanding both the readings and the exercises much more.

b. Reading-oriented lessons: Throughout the six observations, learners were taught reading- oriented lessons in English. Never did the teacher do listening, speaking, or writing related activities. Oral Communication activities were not developed though they are part of the methodological approach of the English Syllabus.

c. Incongruence between the linguistic objectives of the trimestral plan and the objectives developed in class:

Although the teacher's trimestral plan included the development of linguistic objectives for all the macro skills, all the observations evidenced that the only objectives all the lessons dealt with were those related to the reading skill. d. Few Reading Strategies Developed: In NPO1 to NPO4, the only reading strategies that students used were direct cognitive strategies devised by Oxford (1990) from set B (receiving and sending information). They particularly focused on scanning for details and skimming to get the general idea of a text. Nevertheless, the instructor almost never explained to students how to use a particular reading strategy. Certainly, he took for granted that learners should know that. As to this point, Chacón (2012) pointed out that it is commendable that students know how to develop reading strategies in order to combine and choose the appropriate strategies to accomplish a task. In this way, they can become more independent learners. In NPO5 and NOP6, the teacher taught how to identify the main idea of a text and how to distinguish a main idea from a secondary one. In addition, other direct cognitive strategies such as guessing meaning from context and drawing inferences were developed as well.

\section{Test items that most of eleventh graders failed in the National-High- School-Graduation Examination}

The distribution of items of the 2014 National-High-School-Graduation Test booklet IN-12 comprised three different proficiency levels (acceptable, moderate, and deficient) at the time of analyzing the results. The test booklet contained a grand total of 70 points. A student scoring 49 or more questions was considered acceptable. A pupil scoring from 35 to 48 items was moderate. Last, a student obtaining 34 or less correct answers was deficient. 
The following figure shows the academic achievement per target content (1. Achievements of national athletes; 2. C.R music, arts, crafts; 3. C.R typical food; 4.types of food; 5 . table manners; 6. holidays and celebrations; 7 . natural resource misuse; 8 . National and international tourism; 9. Democracy;10. Diseases; 11. careers and jobs; 12 . science and tech; 13. moral and values) that the students obtained in 2014:

\section{Figure 1}

2014 Academic Achievent on the National - High - School -
Graduation Exam

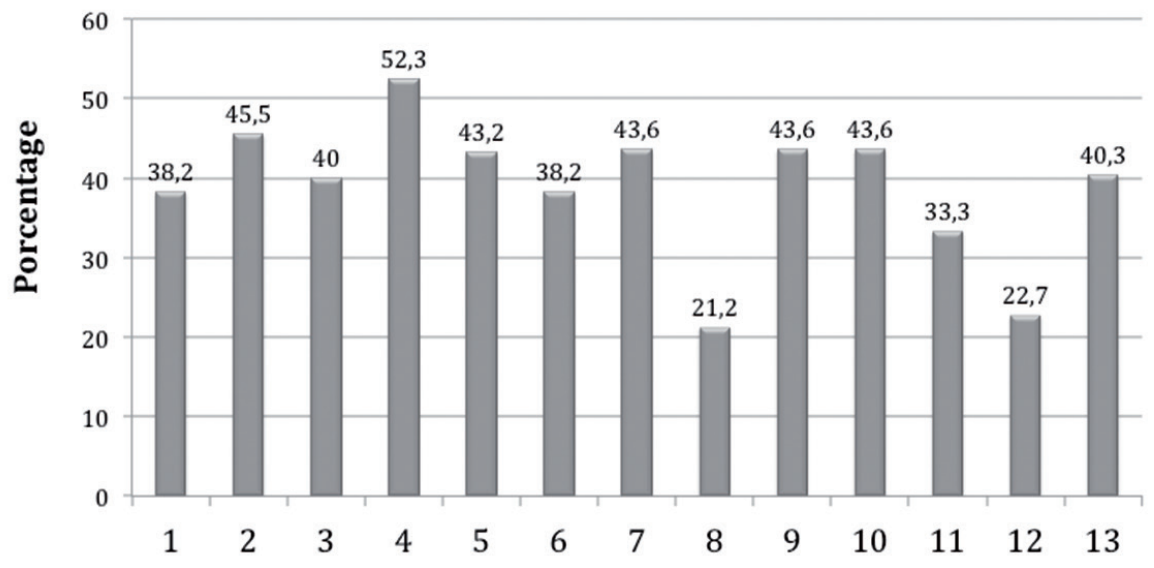

Objective and Content Measured

Source: Data taken from Reports of MEP Board of Quality Control in 2014.

Figure 1 shows evidence that only target content 4 had the easiest questions for the students to answer since $52.3 \%$ of the students got it correct, and target contents $1,6,8,11$, and 12 were the cognitive targets with the hardest questions for the students to answer. Nonetheless, contents 8 and 12 had the lowest achievement. As previously stated, cognitive target 8 was about tourist aspects worldwide and tourist attractions offered by Costa Rican communities and involved the following three linguistic objectives: 1. understanding conceptual meaning, 2. recognizing indicators of discourse, and 3. drawing conclusions from extended texts. Moreover, only $21.2 \%$ of the students answered it correctly. Regarding target content 12 , it focused on science and technology and comprised the following linguistic objectives: 1 . understanding a wide range of factual and imaginative texts, 2. coping readily with unfamiliar topics involving more complex language; and 3. recognizing attitudes and emotions. In fact, only $22.7 \%$ of the students got it correct. In general, all the target contents showed alarming results since the percentage of promotion of each one was rather low. 


\section{Conclusion}

As evidenced in our findings, it is possible to assert that the English teacher developed the contents included in the English Syllabus. In sharp contrast, he was only teaching the linguistic objectives related to the reading skill. The most commonly developed linguistic objectives were: 1 . understanding a wide range of factual and imaginative texts; and 2. coping readily with unfamiliar topics involving more complex language and recognizing attitudes and emotions. Some objectives like distinguishing the main idea from supporting details and drawing conclusions from extended texts were absent from the reading activities he developed. Nonetheless, he used activities that contained inferences after he was coached by the researchers. The teacher was not probably used to teaching inferences to students. In addition, other reading-oriented objectives such as guessing meaning from context or making inferences were also developed after the teacher got some coaching from the researchers though the teacher's first material had some items with a key word in the question that had a synonym in the correct answer. Namely, the answers to items could not be literally found in the text. The students were supposed to use context clues to get the meaning across, but they were never taught how to guess meaning from context. Last, the teacher's trimestral plan evidenced that the target contents were going to be taught in light of the tenets of the four skills because there were linguistic objectives for listening, speaking, and writing, but that never happened although the teacher taught the lesson in the target language.
As to how the teacher was teaching the cognitive targets and objectives, it is possible to assert that the instructor's methodology was rather weak in relation to the following aspects: the role of the teacher, the material used, reading stages, reading strategies, and techniques. The teacher was a class manager. Certainly, there was no evidence of a clear reading approach for teaching reading, considering that the teacher most of the time quickly presented a topic on the board and then distributed copies to students for them to read some short passages and do a set of comprehension exercises. In sum, there was lack of balanced reading that seeks to scaffold students' comprehension and leads them to academic success as previously stated by Cooper (2014). In sum, the teacher focused on reading comprehension. There was no class discussion related to the target contents under study so that reading was taught with no relation to the other language skills, which certainly hindered the learning process because teaching a language must gradually involve the four skills although there is a focus on a particular skill. Moreover, the role of the students was quite passive, and there was no interaction among themselves, which led to a static classroom environment, for the teacher was in charge of conducting the activities and transmitting knowledge.

With regard to the National-HighSchool-Graduation Examination items from 2014, students got a low percentage of correct items in relation to the contents and objectives measured. The most difficult objectives were those about drawing inferences and learning context clues. The students showed vocabulary and reading strategy gaps 
they need to bridge. They lack knowledge of basic words such as verbs (need, want, have, drink, cook, read, write, eat, watch, like, speak and so on); nouns (ordinal and cardinal numbers, time expressions, food, diseases, likes and dislikes, and the like); and structures (parts of speech, verb tenses). In order to overcome vocabulary issues, they need to use dictionaries and other reference aids, word parts (parts of speech), and context clues as proposed by Armbruster and Osborn (2001). Although the teacher developed reading exercises and practices similar to the National-High-School-Graduation Examination items, they were based on rote learning and focused on scanning for details. That is why the students could find the answer mechanically and easily.

Last, through this study, it is possible to claim that every language teacher needs to be careful with the methodology he chooses at the time of planning his lessons. This selection must be made considering the students' needs, situational context, classroom climate, learner types, cultural background, prior knowledge, strategies, and techniques. Although a teacher's methodology is a key factor to consider for lesson planning in order to reach success or failure, it is not the only one. In fact, motivation, attitude, aptitude, embarrassment, anxiety, learner type, and self-confidence do influence academic achievement. Hence, language teachers should regard these elements at the time of devising reading material and lesson procedures.

\section{Bibliography}

Armbruster, B. A., \& Osborn, R. O. (2001). Put Reading First: The Researcha Building Blocks for Teaching Children to Read. (R. A. Adler, Ed.). Jessup, MD: National Institute for Literacy.

Bolos, N. B. (2012). Successful Strategies for Teaching Reading to Middle Grades English Language Learners. Middle School Journal. Retrieved November, 2014, from ERIC database.

Brown, H. D. (2001). Teaching by Principles: An Interactive Approach to Language Pedagogy (2nd ed.). San Francisco, CA: Longman.

Chacón, X. (2012, January). The English Reading Comprehension Class: In-Reading and Post Reading Strategies. Letras, 34, p. 43-58.

Cooper, D. (2014). Literacy: Helping Students Construct Meaning. Stanford, CT: Wadsworth Publishing.

Domian, C. et al (2010, August). La Enseñanza Comunicativa del Inglés en el Ciclo Diversificado en Costa Rica: Imágenes de Algunas Realidades. Letras, 47. Retrieved November 1, 2014, from ERIC database.

Jesness, J. (2004). Teaching English to Language Learners K-12: A QuickStart Guide for the New Teacher. Thousand Oaks, CA: Corwin Press.

Larsen-Freeman, D. (2000). Techniques and Principles in Language Teaching. New York, NY: Oxford University Press.

Lindsay, C. \& Knight, P. (2006). Learning and Teaching English. New York, NY: Oxford University Press.

Ministerio de Educación Pública. (2001). Programa de Estudios de 
Inglés: Educación Diversificada. San José, Costa Rica: El Ministerio. Ministerio de Educación Pública. (2012). Acta Oficial de los Resultados de las Pruebas Administradas en el Curso Lectivo del Bachillerato Formal. San José, Costa Rica: Dirección de Gestión y Evaluación de la Calidad. Ministerio de Educación Pública. (2013). Acta Oficial de los Resultados de las Pruebas Administradas en el Curso Lectivo del Bachillerato Formal. San José, Costa Rica: Dirección de Gestión y Evaluación de la Calidad. Ministerio de Educación Pública. (2014). Acta Oficial de los Resultados de las Pruebas Administradas en el Cur- so Lectivo del Bachillerato Formal. San José, Costa Rica: Dirección de Gestión y Evaluación de la Calidad. Nunan, D. (2003). Practical English Language Teaching. New York, NY: McGraw-Hill.

Oxford, R. (1990). Language Learning Strategies: What Every Teacher Should Know. Boston, MS: Heinle \& Heinle Publishers.

Visser, E. \& Hanggi, G. (2003). Guided Reading in a Balanced Program. Westminster, CA: Teacher Created Materials Inc.

Wiriyachitra, A. (1995, October). The Roles of the Teacher in the Reading Classroom. FORUM, p. 43-44.

\section{Annex 1: Teacher Questionnaire}

The following questionnaire is aimed at gathering data to carry out an investigation project. Please answer each question clearly and honestly. Any information you provide will be used for academic purposes only and dealt with confidentiality. Thank you very much for your time and consideration.

\section{Objective of the questionnaire:}

1. To describe how the teacher teaches reading comprehension to the students for the National-High-School-Graduation Examination.

\section{Research question:}

1. How does the EFL teacher teach reading comprehension to eleventh graders for the National-High-School-Graduation Examination?

I-Part: Answer the questions below.

1. How old are you?

a. Between 25-29 years

b. Between 30-34 years

c. Between 35-40 years

d. Older than 40years 
2.What is your academic degree?
a) Bachelor's
b) Licentiate's
c) Master's
d) $\mathrm{Ph} . \mathrm{D}$

3.For how long have you taught English?
a) 1 year
b) Between 2-4 years
c) Between 5-9 years
d) More than nine years

4. For how long have you taught English at Liceo Concepción?
a) 1 year
b) Between 2-4 years
c) Between 5-9 years
d) More than nine years

5.What grade levels have you taught?

6. How many senior generations have you taught?

a. 1 generation

b. Between 2-4 generations

c. Between 5-7 generations

d) More than 7 generations

7. Use the scale below to give your opinion about the following criteria:

SA: Strongly Agree
A: Agree
D: Disagree
SD: Strongly Disagree

\begin{tabular}{|c|c|c|c|c|}
\hline $\begin{array}{l}\text { CRITERIA RELATED TO YOUR TEACHING } \\
\text { METHODOLOGY }\end{array}$ & $\mathbf{S A}$ & $\mathbf{A}$ & $\mathbf{D}$ & SD \\
\hline \multicolumn{5}{|l|}{ I focus my lessons mainly on reading comprehension. } \\
\hline \multicolumn{5}{|l|}{$\begin{array}{l}\text { I provide students with lists of verbs and vocabulary related to the } \\
\text { target contents developed for them to memorize. }\end{array}$} \\
\hline \multicolumn{5}{|l|}{$\begin{array}{l}\text { I follow the distribution of objectives and contents for the National } \\
\text { Examination rather than the English Syllabus. }\end{array}$} \\
\hline \multicolumn{5}{|l|}{ I am willing to try new teaching methodologies and techniques. } \\
\hline $\begin{array}{l}\text { In my reading lessons, I develop the three stages of the reading } \\
\text { process (Pre-reading, while-reading and post-reading). }\end{array}$ & & & & \\
\hline
\end{tabular}




\begin{tabular}{|l|l|l|l|l|}
\hline $\begin{array}{l}\text { I use copies of readings with or without exercises from printed or } \\
\text { online magazines, newspapers or EFL textbooks. }\end{array}$ & & & & \\
\hline $\begin{array}{l}\text { I invest a lot of time planning my lessons and devising reading } \\
\text { materials for my students. }\end{array}$ & & & & \\
\hline I follow a commercial ESL textbook to teach reading. & & & & \\
\hline
\end{tabular}

8. What is your opinion about the National-High-School-Graduation Test of English (Bachillerato)?

9. How do you think students learn best English?

10. What is your methodology for preparing students for the National-HighSchool-Graduation Examination of English?

11. What kind of materials do you use to teach reading?

12. What techniques do you use to prepare students for the National-HighSchool-Graduation Test(Bachillerato)?

13. From your perspective, what is the best way of teaching reading?

14. How do students react toward the reading activities implemented in class?

15. What specific actions have you and the school administration developed this year to increase the National-High-School-Graduation Examination- Promotion Rate as compared to the low-test promotion obtained last year?

\section{Annex 2: Lesson Observation Sheet}

\section{Objectives of the observation:}

1.1. To identify what target contents and linguistic objectives the teacher teaches to eleventh graders as part of his teaching methodology.

1.2. To describe how the teacher teaches reading comprehension to the students for the National-High-School-Graduation Examination.

\section{Research questions:}

2.1. What target contents and linguistic objectives does the English teacher use with eleventh graders as part of his teaching methodology? 
2.2. How does the EFL teacher teach reading comprehension to eleventh graders for the National-High-School-Graduation Examination?

Lesson Observation Form \#

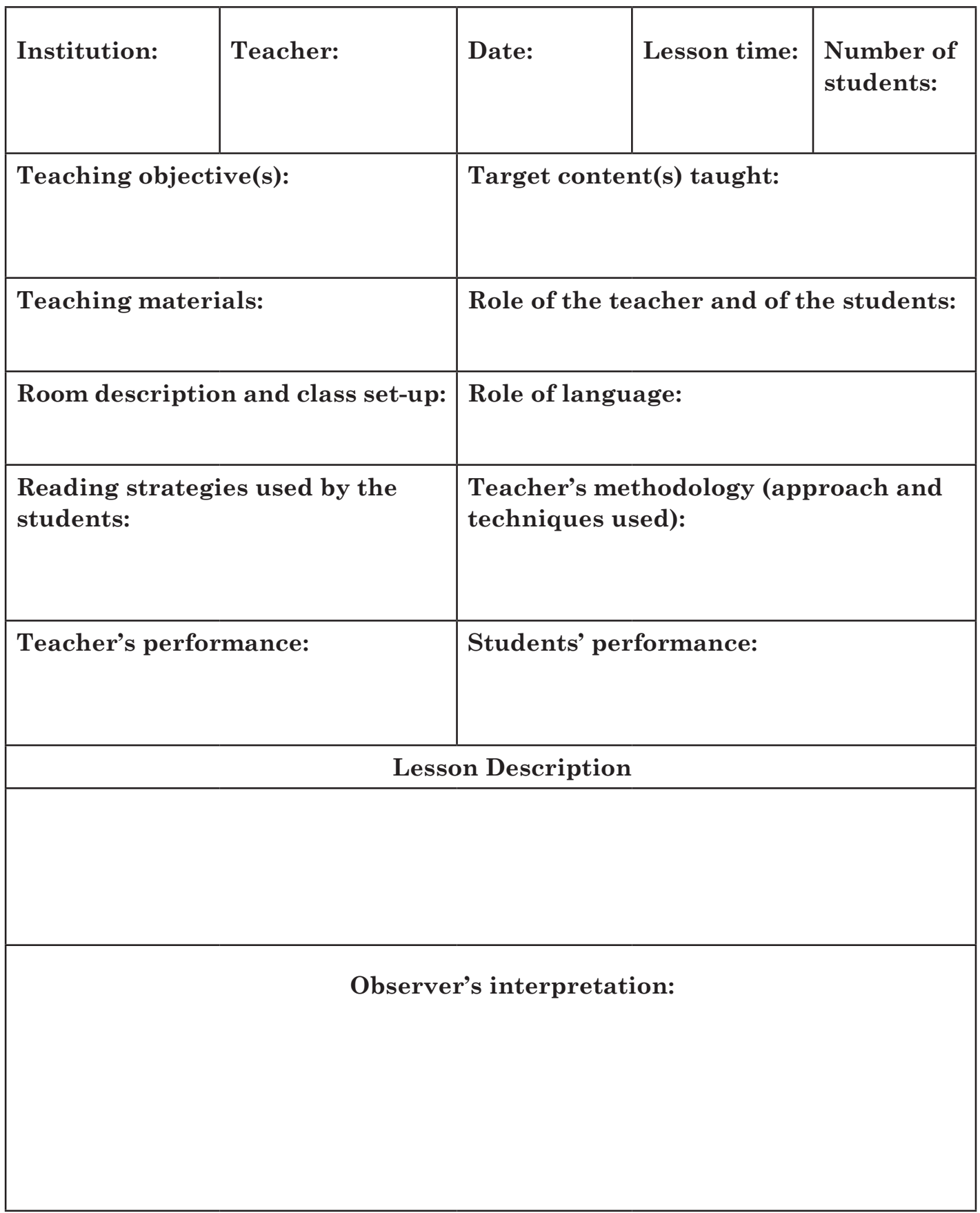


